\title{
The Effect of Culture Type on the Length of Persian Proverbs Compared to their English Equivalents
}

\author{
Amir Mohammadian \\ Department of English Language and Linguistics, Faculty of Management and Humanities, Chabahar Maritime University, Iran \\ E-mail: amir.mohamadian@cmu.ac.ir
}

Received: 09-12-2016

Published: 01-07-2017
Accepted: 18-03-2017

doi:10.7575/aiac.ijalel.v.6n.4p.234
Advance Access Published: April 2017

URL: http://dx.doi.org/10.7575/aiac.ijalel.v.6n.4p.234

\begin{abstract}
The interrelation of culture and language is to the extent that many classifications of culture are based on linguistic factors. In this article, high and low context cultures division is assessed on English and Persian as they belong to different cultural types. Forty Persian proverbs are contrasted with their equivalents in English to investigate whether there is a difference in the number of word forms used in each. In order to avoid linguistic differences which are effective in enumerating word forms, the second lines in linguistic glosses provided for Persian proverbs including a one to one correspondence of each word in English are used to count word forms. Results show that 70 percent of the Persian proverbs in the data are longer than their English counterparts. This shows that relative length of proverbs can be a distinguishing factor reflecting cultural types. The results not only confirm the applicability of this cultural division in the field of proverbs, but also a matter of tendency rather than a dichotomy in belonging to a high or low context culture is proposed. At the end, there are suggestions for further relevant investigations.
\end{abstract}

Keywords: Culture, High context culture, Low context culture, proverb, length of proverb

\section{Introduction}

Culture is such a broad concept that is sometimes hard to define exactly to the extent that Williams considered it as "one of the two or three most complicated words in English language" (Williams, 1976, p. 25). One of the early and comprehensive definitions is "...that complex whole which includes knowledge, belief, art, morals, law, custom, and any other capabilities and habits acquired by man as a member of a group" (Taylor, 1871, p. 1). Spencer- Oatey and contributors define culture as "A set of basic assumptions and values, orientations to life, beliefs, policies, procedures and behavioral conventions that are shared by a group of people, and that influence (but do not determine) each member's behavior and his/her interpretations of the 'meaning' of the other people's behavior" (Helen Spencer- Oatey and contributors, 2013, p. 3). Another definition of culture goes as "The shared patterns of behaviors and interactions, cognitive constructs, and affective understanding that are learned through a process of socialization. These shared patterns identify the members of a culture group while also distinguishing those of another group" (What is Culture?, 2014).

Language in its general sense as a shared system among users within the same culture if not being influenced by it, then at least interplays with culture as expressed in different versions of Sapir-Whorf hypothesis. Although the vocabulary items and semantic networks existing in a language can reveal much about the cultural values within a society, it is not the only part of language. All other aspects of a language including sentence length and structures and the way language users express what they think or feel may differ from culture to culture. For example, Galanti reports a case in which a female patient died in a hospital because of a cultural difference in expressing pain with his doctor. Since Indian women are usually vocal and exaggerate when in pain, the Indian doctor ignored her Irish patient's complaints about her pain and this was while Irish people are stoic in pain (Galanti, 2004, pp. 42-43).

Cultures are of different types and different characteristics and behaviors of people belonging to each culture are the basis of the various classifications made by scholars. Some of these classifications of cultures are relevant to the linguistic aspect and the ways people in each culture use language in order to communicate with each other. For instance, Hall (1976) made a distinction between cultures in which much is conveyed through contextual elements in communications and cultures in which more explanation is necessary because the message itself tends to contain the intended information and consequently the same message may be of different length in each culture type.

This article is going to compare contemporary Persian with English language according to high-low context cultures dichotomy presented by Hall (1976). Among the different linguistic forms, proverbs are studied in this research based on cultural differences since proverbs are not only among the linguistic areas revealing the culture of its speakers (Rong, 2013, p. 31) but also as Grzybek (2004) states proverbs have not been yet seriously investigated regarding underlying structures and regularities. Hence, some of the proverbs in English and their counterparts in Persian are contrasted in terms of their length and the number of word forms existing in each seeking the answer to the question to 
the effect that whether there is a difference in the length of Persian proverbs with their English equivalents since they belong to different culture types.

\section{Literature review}

Although there are many different classifications available in typology of cultures, some of them are not much relevant to the linguistic behavior of individuals living in each one. In this group, Benedict's distinction between Apollonian versus Dionysian cultures is an instance in which the former values modesty and peace and the latter prefers achieving excess and illuminations of frenzy (Benedict, 1934). Other examples include real versus ideal culture, traditional versus modern cultures and so on.

As for the second group of classifications, Hofstede (1991) categorizes cultures according to five dimensions. Power distance relates to the way a culture accepts and deals with inequalities in terms of power status between communicators and hence cultures can be large or small in this regard. For example, Arabic countries or Mexico are among large power distance cultures in which participants in a conversation having lower status tend to accept and respect the higher one(s). The second dimension is avoidance of uncertainty by which some cultures like Japan avoid uncertainty and prefer strict statements while people from cultures tolerating uncertainty accept rough and vague information. Individual and collective dichotomy is another way of classifying cultures that focuses on the importance given by members of a culture to their own or their society. This, in fact, relates to the self-concept of speakers within a culture considering themselves as "I" or "We". Masculinity is another factor distinguishing cultures by which cultures will be masculine or not. While in a masculine culture assertiveness is dominant, a non-masculine culture is unassertive. Orientation to time divides cultures into monochromic and polychromic. In monochromic cultures like Canada, the notion of time differs from what people mean in polychromic cultures since in polychromic cultures multiple tasks are possible, interruptions are acceptable and punctuality is not a necessity. In addition, cultures can be of past, present or future oriented types and hence conservative or optimistic (Hofstede, 1991).

Trompenaars divides cultures into neutral and affective based on the range of expressing feelings. People in an affective culture usually express their emotions more freely (Trompenaars, 1993).

Triandis distinguishes between complex and simple cultures such that in a complex culture there are much more distinctions between phenomena and entities around. Tight and loose cultures are also among his classifications of cultures. In tight cultures, innovations are rare and bounding to norms is more acceptable while loose cultures either are tolerant about deviations or have no clear norms (Triandis, 1994).

There are still many other divisions on culture types and one of them based on which this research is going to be done is the one presented by Hall (1976). In this classification, cultures are categorized according to different factors such as proxemics, chronemics and contexts. In context-based categorization, cultures may be high or low. In high context cultures, much of the intended information is dependent on the immediate context and many things are not said explicitly within a communication while in low context cultures, the message itself bears the main part of the required information and hence the same message in a high context culture is usually shorter in length (Hall, 1976, p. 79). Therefore, in high context cultures, the burden of conveying the message in a communication is on the preceptor and in low context cultures, it is the producer of the message who plays the main role (Zahrana, 1995). Accordingly, Scandinavian countries, Germany, and the U.S. are among low and Japan, China, Arab Countries and Iran are among high context cultures (Ferraro, 1994, p. 51). Rong (2013, p. 33) discusses the role of silence in high and low context cultures and concludes silence is more preferable to conversation in high context cultures such as Japan. Hall (1976, p. 79) states that in high context cultures nonverbal communication is used more. Hence, if the immediate context is unavailable as in the case of written messages, phone calls, contracts or fixed sentences, the intended message will be of greater length compared to low context cultures. An example is a written text on shop doors as "no ice cream" in English language as a low context culture while in Persian it is written as "Do not enter with ice cream" literally. According to this, in this article, a comparison is made between some proverbs, as fixed sentences capable of being addressed to everyone, in Persian and their equivalents in English to see if there is a difference in their size and length since these languages are different in terms of high and low context dichotomy.

\section{Scope and methods}

One of the comprehensive definitions found in (Hassan Zolfaghari, Hayat Ameri, 2012, p. 93) defines the term proverb as:

"A proverb is a short sentence, which is well-known and at times including advice, sage themes and ethnic experiences, comprising simile, metaphor or irony which is well-known among people for its fluent wording, clarity of expression, simplicity, expansiveness and generality and is used either with or without change"

A close look at proverbs in different languages, namely Persian and English here, reveals that semantically they can be grouped in three classes. Firstly, some of the proverbs exist in one languge but their equivalents do not exist in the other. For example, the English proverb Revenge is sweet does not have a counterpart in Persian. Secondly, ignoring the word order differences, some of the proverbs having the same meaning in both languages use exactly the same vocabulary items albeit with a different ordering. For instance, the English proverb Prevention is better than cure in Persian exists with total equality except for the syntactic differences as 'Prevention better than cure is'. Third, there are 
proverbs in both languages which are used in the same context but with different vacabulary items. In other words, proverbs of the third class are semantically and contextually the same while structurally different like Actions speak louder than words which in Persian exists literally as 'two handred statements are not like half of an action'. In this paper, only the third group of the proverbs comprises the scope of investigation.

Forty randomly selected American English proverbs of the third group above have been chosen from (Collis, 1992) to be contrasted and checked based on Hall's high and low context cultures dichotomy with their Persian counterparts. In order to do this, first an English proverbs comes and then its Persian equivalent is studied using lingustic glosses in which the first lines contain phonetic transcriptions according to (Full IPA Chart, 2015) and the second lines include a one to one correspondence of each word in English. After that, they must be contrasted in terms of their length by counting the number of words used in each. Since determining and counting words might be a problematic task, the distinctions made in (Francis Katamba, John Stonham, 2006) between different types of words is taken and only separate word forms in each proverb are counted. In order to have equvalence in the items contrasted and meet the Tertium Comparationis requirement, it seems wise to consider the second lines rather than the first ones to avoid linguistic differences which are effective in enumerating word forms. For instance, in Persian possessive pronouns are among suffixes and hence attached to another word and not counted separately while in English they can stand alone and comprise a single word form. As another example, the object marker "ro" in Persian has no equivalence in English. It should be noted that there are some differences between these two languages which may in some cases make the second lines hard to understand for readers. For example, the dominant word order pattern in English is SVO while in Persian it is SOV (Mahootian, 2008, p. 286), double negation in Persian is possible (Kwak, 2010), Persian is a pro drop language and hence there may be some sentences without overt subjects (Mahootian, 1997, p. 48) or in Persian bare singular nouns can stand as noun phrases (Ghomeshi, 2008). That is why the third line of glosses is allocated to a literal translation of Persian proverbs into English.

\section{Analysis and results}

In this part first, forty English proverbs followed by the related glosses as mentioned before are listed. The number of word forms used in each proveb in English and Persian (second line of glosses) comes briefly at the end of each item. At the end, there are tables summerizing the results.

1- Birds of a feather flock together

$\begin{array}{clrllllll}\text { /kæbutær } & \text { bv } & \text { kæbutær } & \text { bpz } & \text { bv } & \text { bpz } & \text { konæd } & \text { hæmjens } & \text { bp } \\ \text { dove } & \text { with } & \text { Dove } & \text { hawk } & \text { With } & \text { Hawk } & \text { Does } & \text { congener } & \text { with } \\ \text { hæmjens } & \text { pærvbz/ } & & & & & & & \\ \text { congener } & \text { fly } & & & & & & \end{array}$

'Dove with dove, hawk with hawk, congeners fly with congeners'

English: 6 word forms, Persian: 11 word forms

2- In unity there is strength

$\begin{array}{llll}\text { jek } & \text { dæst } & \text { sedp } & \text { nædpræd/ } \\ \text { one } & \text { hand } & \text { Sound } & \text { does not have }\end{array}$

'One hand does not have sound'

English: 5 word forms, Persian: 6 word forms

3- A man is known by the company he keeps

$\begin{array}{cccccc}\text { /begu } & \text { dustæt } & \text { Kist } & \text { to } & \text { begujæm } & \text { kisti/ } \\ \text { tell } & \text { your friend } & \text { who is } & \text { so } & \text { tell I } & \text { who are you }\end{array}$

'Tell who your friend is, so I tell who you are'

English: 9 word forms, Persian: 11 word forms

4- Misery loves company

$\begin{array}{lllclll}\text { /xærmæn } & \text { suxte } & \text { Hæme } & \text { ro } & \text { xærmæn } & \text { suxte } & \text { xphæd/ } \\ \text { harvest } & \text { burned } & \text { everybody } & \text { object marker } & \text { harvest } & \text { burned } & \text { wants }\end{array}$

'A harvest burned person wants everybody harvest burned'

English: 3 word forms, Persian: 6 word forms 
5- Too many cooks spoil the broth

/pjpæz ke dotp befe qæzp Ja Jur mifævæd jp binæmæk/

cook when two becomes food whether Salted becomes or unsalted

'When cooks become two, the food becomes whether salted or unsalted'

English:6 word forms, Persian: 10 word forms

6- If you can not beat them, join them

/dæsti ke be dændpn nætævpn Bord bebus/

a hand that to Teeth can not Take Kiss

'Kiss the hand that can not be taken to teeth'

English: 8 word forms, Persian: 9 word forms

7- Leave well enough alone

/særi ke dærd Nemikonæd ro dæstmpl nemibændænd/

a head that ache does not object marker Kerchief do not tie

'A head that does not ache is not tied with kerchief'

English: 4 word forms, Persian: 10 word forms

8- Look before you leap

/bi godpr be pb næzæn/

impassably into water do not hit

'Do not hit the water impassably'

English: 4 word forms, Persian: 6 word forms

9- When in Rome do as the Romans do

/xphi næeævi rosvp Hæmrænge jæmp?æt bp $\int /$

you want not to become conspicuous congruent to crowd $\mathrm{Be}$

'If you want not to become conspicuous, be congruent to the crowd'

English: 8 word forms, Persian: 10 word forms

10-All that glitters is not gold

/hær gerdi Gerdu nist/

every round thing wulnut is not

'Every round thing is not wulnut'

English: 6 word forms, Persian: 6 word forms

11- Do not bite the hand that feeds you

/næmæk xordæn væ næmækdpn Jekæstæn/

Salt eating and saltshaker breaking

'Eating salt and breaking saltshaker'

English: 8 word forms, Persian: 5 word forms 
12- Forewarned is forearmed

/ælpje vpqe?e qæblæz voqu? bpjæd kærd/

remedy of incident before occurrence Must to do

'Remedy of incident must be done before occurrence'

English: 3 word forms, Persian: 8 word forms

13- No pian no gain

/npborde rænj gænj mojæssær nemifævæd/

Untaken pain Treasure possible does not become

'Treasure does not become possible without taking pains'

English: 4 word forms, Persian: 7 word forms

14- Practice makes perfect

/kpre niku kærdæn æz por Kærdæn æst/

act good doing due much Doing Is

'Doing a good act is due to doing it much'

English: 3 word forms, Persian: 7 word forms

15- Clothes do not make the man

$\begin{array}{lllllll}\text { /tæne } & \text { pdæmi } & \text { færif } & \text { Æst } & \text { be } & \text { jone } & \text { pdæmijat } \\ \text { body of } & \text { humankind } & \text { Honorable } & \text { Is } & \text { to } & \text { spirit of } & \text { being human } \\ \text { næ } & \text { hæmin } & \text { lebpse } & \text { zibpst } & \text { nefpne } & \text { pdæmijæt/ } & \\ \text { Not } & \text { This } & \text { Clothing } & \text { nice is } & \text { sign of } & \text { being human }\end{array}$

'The body of humankind is honorable due to the spirit of being human, this nice clothing is not the sign of being human'

English: 6 word forms, Persian: 19 word forms

16- Money does not grow on trees

/pul ælæfe xers nist/

money grass of bear is not

'Money is not bear grass'

English: 6 word forms, Persian: 6 word forms

17- One swallow does not a summer make

/bp jek gol bæhpr nemiðævæd/

with one flower spring does not become

'Spring does not come with one flower'

English: 7 word forms, Persian: 7 word forms

18- The apple does not fall far from the tree

/tære be toxmes mire Hæsani be bpbpf/

leek To its seed likens Hasani (a proper name) to his father 
'Leek gets like its seed, Hasani like his father'

English: 9 word forms, Persian: 9 word forms

19- Barking dogs seldom bite

$\begin{array}{lllllll}\text { /æz } & \text { pn } & \text { nætærs } & \text { ke } & \text { hpjohu } & \text { dpræd } & \text { æz } \\ \text { of } & \text { that } & \text { do not fear } & \text { who } & \text { ballyhoo } & \text { Has } & \text { of } \\ \text { pn betærs } & \text { ke } & \text { sær } & \text { be } & \text { Tu } & \text { dpræd/ } \\ \text { that fear } & \text { who } & \text { head } & \text { to } & \text { down/ inside } & \text { has }\end{array}$

'Do not fear that who has ballyhoo, fear that who has head down'

English: 4 word forms, Persian: 16 word forms

20- A leopard can not change his spots

/pqebæt gorgzpde gorg Jævæd gærçe bp pdæmi bozorg Jævæd/

finally werewolf wolf becomes even With humankind grown-up becomes

'Finally, a werewolf becomes wolf even if (it) gets grown-up with humankind'

English: 7 word forms, Persian: 9 word forms

21- You can not have your cake and eat it too

hæm xodp ro mixaphæd hæm xormp rp/

also God object marker s/he wants also dates object marker

'S/he wants both God and dates'

English: 10 word forms, Persian: 6 word forms

22- A fool and his money are soon parted

/xær çe dpnæd Qejmæte noql O næbpt/

donkey what knows price of sweets and Candies

'Donkey does not know the price of sweets and candies'

English: 8 word forms, Persian: 8 word forms

23- Old habits die hard

/tærke pdæt mojebe mæræz æst/

Leaving habit cause of disease Is

'Leaving habits is the cause of disease'

English: 4 word forms, Persian: 6 word forms

24- One man's gravy is another man's poison

/ælæf bpyæd be dæhæne bozi Jirin bijpd/

grass should to mouth of goat sweet Seems

'Grass should seem sweet to the mouth of goat'

English: 7 word forms, Persian: 8 word forms 
25- When the cat is away the mice will play

/ $æ$ æhr ke bi kælpntær befe qurboqe haft tirkef mife/

city when without sheriff becomes Frog gunfighter gets

'When city becomes without sheriff, frog gets gunfighter'

English: 9 word forms, Persian: 8 word forms

26- Blood is thicker than water

/çpqu Dæsteje xodæ $\int$ ro nemiboræd/

knife hand of its own object marker does not cut

'A knife does not cut its own hand'

English: 5 word forms, Persian: 8 word forms

27- A friend in need is a friend indeed

/dust pn bpjæd ke giræd dæste dust dær pærifpnhpli o dærmpndegi/

friend that is who takes hand of friend in distress and insolvency

'A friend is the one who takes the hand of a friend in distress and insolvency'

English: 8 word forms, Persian: 12 word forms

28- Love is blind

/e pq pdæm ro kur mikonæd/

love human object marker blind Makes

'Love makes human blind'

English: 3 word forms, Persian: 4 word forms

29- Better late than never

/dir residæn behtær æz hærgez Næresidæn æst/

late arriving better than never/at all not arriving is

'Arriving late is better than not arriving at-all'

English: 4 word forms, Persian: 8 word forms

30- Better safe than sorry

/çerp pqel konæd kpri ke bpz præd pæfimpni/?

why sage does Something that again brings regret?

'Why a sage does something that brings regret later?'

English: 4 word forms, Persian:8 word forms

31- A bird in the hand is worth two in the bush

/serkeje næqd beh æz hælpvje nesije/

vinegar cash better than Halva (Iranian confection) credit

'Cash vinegar better than credit halva'

English: 11 word forms, Persian: 6 word forms 
32- Charity begins at home

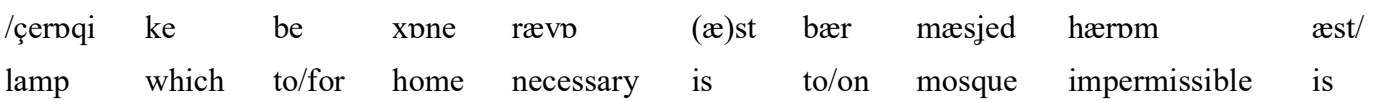

'A lamp which is necessary for home is impermissible to the mosque'

English: 4 word forms, Persian: 10 word forms

33- Haste makes waste

/æjæle kpre Jejtwn æst/

haste work of Satan is

'Haste is the work of Satan'

English: 3 word forms, Persian: 5 word forms

34- Love makes the world go round

læz mohæbbæt xprhp gol mijævæd/

from/by love thorns flower becomes

'By love thorns become flower'

English: 6 word forms, Persian: 5 word forms

35- You reap what you sow

/hærke non æz æmæle xif xorad/

everybody bread of work of himself/herself eats

'Everybody eats the bread of the work of himself/herself'

English: 5 word forms, Persian: 7 word forms

36- The bigger they are, the harder they fall

hær ke bomæe bif bærfæe biftær/

Everyone who his/her roof more his/her snow more

'Everyone who his/her roof is larger, his/her snow is more'

English: 8 word forms, Persian: 8 word forms

37- Good things come in small packages

/felfel næbin çe rize befkæn bebin çe tize/

pepper don not see how small it is snap see how hot it is

'Do not see how small a pepper is, snap it and see how hot it is'

English: 6 word forms, Persian: 14 word forms

38- The grass is always greener on the other side of the fence

/morqe hæmspje qpze/

hen of neighbor goose is

'The hen of the neighbor is a goose'

English: 12 word forms, Persian: 5 word forms 
39- Hindsight is better than foresight

$\begin{array}{llllll}\text { /mo?æmmp } & \text { ço } & \text { hæl } & \text { gæft } & \text { pspn } & \text { Jæavæd/ } \\ \text { puzzle } & \text { when } & \text { solved } & \text { got } & \text { Easy } & \text { becomes }\end{array}$

'A puzzle becomes easy when it gets solved'

English: 5 word forms, Persian: 6 word forms

40- Nothing hurts like the truth

/hæqiqæt mesle kune xijpr tælxe/

truth like bottom of cucumber bitter is

'Truth is bitter like the bottom of a cucumber'

English: 5 word forms, Persian: 7 word forms

Following tables show the results briefly. As it can be seen, English proverbs and their counterparts in Persian fall in three groups.

Table 1. Longer Proverbs in Persian

\begin{tabular}{ccc|ccc}
\hline Proverb Number & English & Persian Counterpart & Proverb Number & English & Persian Counterpart \\
\hline 1 & 6 & 11 & 20 & 7 & 9 \\
\hline 2 & 5 & 6 & 23 & 4 & 6 \\
\hline 3 & 9 & 11 & 24 & 7 & 8 \\
\hline 4 & 3 & 6 & 26 & 5 & 12 \\
\hline 5 & 6 & 10 & 27 & 8 & 4 \\
\hline 6 & 8 & 9 & 28 & 3 & 8 \\
\hline 7 & 4 & 10 & 29 & 4 & 10 \\
\hline 8 & 4 & 6 & 30 & 4 & 5 \\
\hline 9 & 8 & 10 & 32 & 4 & 7 \\
\hline 12 & 3 & 8 & 33 & 3 & 6 \\
\hline 13 & 4 & 7 & 35 & 5 & 7 \\
\hline 14 & 3 & 7 & 37 & 6 & total=28 \\
\hline 15 & 6 & 19 & 39 & 5 & $\%$ \\
\hline 19 & 4 & 16 & 40 & 5 & \\
\hline
\end{tabular}

Table 2. Longer Proverbs in English

\begin{tabular}{ccc}
\hline Proverb Number & English & Persian Counterpart \\
\hline 11 & 8 & 5 \\
\hline 21 & 10 & 6 \\
\hline 25 & 9 & 8 \\
\hline 31 & 11 & 6 \\
\hline 34 & 6 & 5 \\
\hline 38 & 12 & 5 \\
\hline & & \multicolumn{2}{c}{ total $=6$} \\
$\% 15$
\end{tabular}

Table 3. Proverbs with Equal Length in Persian and English

\begin{tabular}{|c|c|c|}
\hline Proverb Number & English & Persian Counterpart \\
\hline 10 & 6 & 6 \\
\hline 16 & 6 & 6 \\
\hline 17 & 7 & 7 \\
\hline 18 & 9 & 9 \\
\hline 22 & 8 & 8 \\
\hline 36 & 8 & 8 \\
\hline & & $\begin{array}{r}\text { total }=6 \\
\% 15\end{array}$ \\
\hline
\end{tabular}


As the tables above show, according to the analyzed data 28 of $40(\% 70)$ proverbs in Persian are longer in terms of the number of word forms used in them compared to their English equivalents. Six English proverbs (\%15) are longer than their Persian counterparts and Six proverbs (\%15) are of equal size in both languages.

\section{Conclusion}

In this article, after briefly introducing the term culture and its relation to language, a short literature of cultural typology with a focus on those related to linguistic aspects was reviewed. One of the classifications presented by Hall (1976) was taken as the framework of the investigation in which cultures are divided into high and low according to the extent of using context in forming a message. Consequently, there can be longer or shorter messages to convey the same information in different languages and cultures if the immediate context is available. In high context cultures, the same messages normally tend to be shorter than those in low context cultures. On the contrary, when context cues are weak or unavailable as in the case of written or pre-established messages, it is the high context cultures that use longer forms. Based on these, this article tried to study the length of proverbs in two languages belonging to different cultural types, namely Persian and English, since proverbs are among the linguistic areas revealing the culture of its speakers (Rong, 2013, p. 31). In order to do it, forty American English proverbs were contrasted with their counterparts in Persian in terms of the number of word forms used in each proverb after restricting the conflicting linguistic differences. Results show that \% 70 of these proverbs are expressed longer in Persian compared to English, \% 15 are longer in English and $\% 15$ are of equal size. The data shows that as Hall (1976) believes culture types affect the way messages are conveyed, that is proverbs as pre-established messages tend to be expressed longer in a language belonging to a high context culture like Persian compared to English which is of a low context culture type. So, it can be concluded that length of proverbs is a distinguishing factor reflecting cultural types. In other words, in a language like Persian, proverbs with the same meaning tend to be explained more compared to English. The results not only confirm the applicability of the high and low context cultures division in the field of proverbs, but also a matter of tendency rather than a dichotomy in belonging to a high or low context culture is proposed. Both languages in the data investigated have longer and shorter cases of expressing the same proverbs with different inclinations to each side.

Proverbs are among problematic areas in learning and teaching a new language (Shelby, 2015). A disparity between the source and target languages in terms of being among high or low context cultures can be one of the sources of difficulty. Hence, studying the effect of making learners aware of this cultural difference on learning proverbs specifically and all aspects of a language generally is a suggestion for further research. Of course, this can be applied to all other cultural differences influencing language use in language teaching contexts to see if explicit awareness of them by learners can make the process of learning a new language more effective.

\section{References}

Benedict, R. (1934). Patterns of Culture. Boston and New York: Houghton Mifflin Company.

Collis, H. (1992). 101 American English Proverbs: Understanding Language and Culture Through Commonly Used Sayings. Lincolnwood (Chicago): Passport Books.

Ferraro, G. P. (1994). The Cultural Dimension of International Business (Second ed.). New Jersey: Prentice Hall, Englewood Cliffs.

Francis Katamba, John Stonham. (2006). Morpholgy (Second ed.). New York: Palgrave Macmillan.

Full IPA Chart. (2015). (IPA Webmaster) Retrieved 6 22, 2016, from International Phonetic Association: https://www.internationalphoneticassociation.org/

Galanti, G. A. (2004). Caring for Patients from Different Cultures (Third ed.). philadelphia: University of Pennsylvania Press.

Ghomeshi, J. (2008). Markedness and bare nouns in Persian. In S. Karimi, V. Samiian, \& D. Stilo (Eds.), Aspects of Iranian Linguistics (pp. 85-112). Newcastle: Cambridge Scholars Publishing.

Grzybek, P. (2004). A Quantative Approach to lexical Structure of Proverbs. Journal of Quantitative Linguistics, 11(12), 79-92. doi:10.1080/092961705123313833665

Hall, E. T. (1976). Beyond Culture. New York: Doubleday.

Hassan Zolfaghari, Hayat Ameri. (2012). Persian Proverbs: Definitions and Characteristics. Journal of Islamic and Human Advanced Research, 2, 93-108.

Helen Spencer- Oatey and contributors. (2013). Introduction. In H. Spencer-Oatey (Ed.), Culturally Speaking: Culture, Communication and Politeness Theory (Second ed.). London: Bloomsbury Academic.

Hofstede, G. H. (1991). Cultures and Organizations, Software of the Mind, Intercultural Cooperation and its Importance for Survival. London: McGraw- Hill International (UK) Limited.

Kwak, S. (2010). Negation in Persian. Iranian Studies, 43(5), 621-636. doi:10.1080/00210862.2010.518028

Mahootian, S. (1997). Persian. London and New York: Routeldge.

Mahootian, S. (2008). Inversion and Topicalization in Farsi Discourse. In S. Karimi, V. Samiian, \& D. Stilo (Eds.), Aspects of Iranian Linguisticcs (pp. 277-288). Newcastle: Cambridge Scholars Publishing. 
Rong, H. (2013). Proverbs Reveal Culture Diversity. Cross-Cultural Communication, 9(2), 31-35. doi:http//dx.doi.org/10.3698/j.ccc.1923670020130902.1346

Shelby, M. (2015). Difficulties and Problems in Learning English. Retrieved 7 2, 2016, from Teach This: http://www.teach-this.com/ideas/problems-learning-english

Taylor, E. B. (1871). Primitive Culture: Researches into the Development of Mythology, Philosophy, Religion, Art, and Custom (Second ed., Vol. 1). University of Michigan: Murray.

Triandis, H. C. (1994). Culture and Social Behavior. New York: McGraw-Hill.

Trompenaars, F. (1993). Riding the Waves of Culture. London: Nicholas Brealey.

What is Culture? (2014, 5 27). (University of Minnesota ) Retrieved 6 22, 2016, from Center for Advanced Research on Language Acquisition (CARLA): http://carla.umn.edu/culture/definitions.html

Williams, R. (1976). Keywords: A Vocabulary of Culture and Society. London: Fontara.

Zahrana, R. S. (1995). Understanding Cultural Preference of Arab Communication- Pattern. Public Relation Review, 21(3), 241-255. 